\title{
ORIGINAL SHELL COLOURATION IN LATE PLEISTOCENE TEREBRATULID BRACHIOPODS FROM NEW ZEALAND
}

\section{Gordon B. Curry}

\section{ABSTRACT}

A Late Pleistocene locality (approx. $80 \mathrm{ka}$ ) in the Wanganui Basin, New Zealand, has yielded large numbers of the brachiopod Calloria inconspicua displaying original shell colouration. In total $78 \%$ out of a collection of 377 fossil shells show orange-red colouration that represents a partial degradation of the stronger red colour found in living representatives. Investigation of a modern-day population of the species from New Zealand from an intertidal habitat indicates that recently deceased individuals rapidly lose all of their colouration. Only $57 \%$ of 281 individuals collected from the sediment surface beneath this modern population retained any trace of shell colour, and this proportion dropped to $46 \%$ of the 321 shells in the top $50 \mathrm{~mm}$ of sediment. As other brachiopods and molluscs at the Late Pleistocene locality also revealed traces of original colouration, preservational conditions must favour the survival of the pigments responsible for shell colouration. The colouration of Calloria inconspicua is caused by a caroteno-protein embedded within the shell, which is susceptible to degradation in the presence of light and oxygen. Rapid burial may retard the processes of degradation, and such an interpretation is consistent with the occurrence of the fossil brachiopods in an intertidal pebble bed. Colouration of the shell may help camouflage the brachiopod; the same colouration in the free-swimming larvae may offer protection from radiation damage.

Gordon B. Curry, Division of Earth Sciences, Gregory Building, University of Glasgow, Glasgow, G12 8QQ, Scotland

KEY WORDS: Pleistocene, shell colour, brachiopod, New Zealand

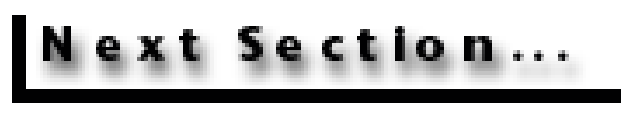

Copyright: Palaeontological Association, October 1999

Submission: 6 June 1999, Acceptance: 9 September 1999 


\section{ORIGINAL SHELL COLOURATION IN LATE PLEISTOCENE TEREBRATULID BRACHIOPODS FROM NEW ZEALAND}

\section{PLAIN LANGUAGE SUMMARY:}

Colouration rarely survives in fossils, as fossilisation processes usually destroy any colouration present in the organism during life. In exceptional circumstances, however, colour patterns are preserved on the surface of fossil shells as brown or black markings. The survival of fossils with their original colouration preserved, as described in this paper, is even more unusual. In this case over $78 \%$ of the shells of the brachiopod Calloria inconspicua from an 80,000 year-old Pleistocene locality in New Zealand show traces of their original red shell colouration. These fossils lived on boulders in a very shallow marine habitat. The species is still living in New Zealand, and an investigation of a modern population from an intertidal habitat indicates that such a high proportion of colour survival is unusual. Only $57 \%$ of 281 recently deceased individuals collected from the sediment surface beneath this modern population retained any shell colour, and this proportion dropped to $46 \%$ of the 321 shells found in the top $50 \mathrm{~mm}$ of sediment. Other fossil shells at the Late Pleistocene locality also revealed traces of preserved colouration, indicating that preservational conditions must favour the survival of shell colouration. The colouration of Calloria inconspicua is caused by a caroteno-protein, a bright red molecule formed from a protein attached to one or more brightly colored carotenoids (the molecules responsible for the colour of tomatoes and carrots). The caroteno-protein is embedded within the shell of Calloria inconspicua, and these types of molecules are known to be susceptible to degradation in the presence of light and oxygen. It seems likely, therefore, that the fossil shells were buried very rapidly in such a way as to exclude long-term exposure to oxygen, light, and other degradational agents. Detecting colouration in the remains of ancient organisms has considerable palaeo-biological significance, providing information on how these ancient organisms lived, how they interacted with other organisms, and how they evolved. Colouration of the shell may help warn off predators or camouflage the brachiopod; the same colouration in the free-swimming larvae may offer protection from UV-radiation, which can damage DNA.

Gordon B. Curry, Division of Earth Sciences, Gregory Building, University of Glasgow, Glasgow, G12 8QQ, Scotland (G.Curry@earthsci.gla.ac.uk) 


\section{INTRODUCTION}

Preservation of colour patterns on fossil shells is a rare phenomenon, but has been recorded throughout the Phanerozoic (see review in Hoare 1978). In the overwhelming majority of cases, such reports describe the discovery of brown or blackish marks on the surfaces of shells that are presumed to be the faded remains of more vivid in vivo colouration. The colour of an organism is caused either by 'structure' (i.e., interference patterns) or by coloured molecules (pigments) associated with, or embedded within, body tissues and shells (Fox and Vevers 1960). The latter is by far the most common in marine organisms, although it is clear that these pigmented molecules do not often survive the fossilisation process. Pigments do survive as molecular fossils (Blumer 1965), but decay to the extent that they no longer absorb light at particular wavelengths. Such a phenomenon would explain the survival of colour patterns, but not the original colouration. It would also explain reports of the detection of coloured fossils that rapidly fade after excavation. Both light and oxygen strongly degrade pigments and exposure to both would rapidly break bonds in the molecule and change its light absorbance, and hence its colour, and that of the shell or tissue in which it occurs (Cheesman et al. 1967).

This paper describes the discovery of relatively stable and undoubtedly genuine colouration in a population of Upper Pleistocene marine shells from New Zealand. Even in these relatively recent fossils, the survival of original colour is very patchy. The coloured fossils have been found only in one small locality at this horizon, exposures of which extend for several kilometres along the coastal section and in various inland exposures.

The main focus of this study is on the survival of coloured brachiopods. The Brachiopoda are a phylum with an extensive record of preserved shell colour patterns on specimens extending back at least to the Devonian Period (Blodgett et al. 1988). Most examples are terebratulids, although there are also some records of rhynchonellids with well-preserved colour patterns (Biernat 1984). Investigations of the preservation of undoubtedly original shell colouration, as opposed to colour patterns, are of interest for several reasons. Firstly such studies are a significant contribution to the investigation of biomolecular survival in the fossil record, especially as the biochemical basis of shell colouration has been determined in at least one Recent brachiopod (Curry et al. 1991; Cusack et al. 1992). Secondly shell colouration has a number of ecological implications that could be extended backward in time if detection in fossils occurred and the preservation criteria were understood. Thirdly there are evolutionary considerations (when and how did colour evolve?; does it have a similar biochemical basis in different groups of brachiopods?) that are best approached from a combined study of living brachiopods and their fossilized ancestors.

To this end, this paper also describes the result of a comparison of the colour distribution on living and recently dead brachiopods from a comparable, present day 
ecological setting. Calloria inconspicua [formerly known as Waltonia inconspicua or Waltonia (Terebratella) inconspicua (Cooper and Lee 1993)] is the most abundant living brachiopod around the coast of New Zealand and is found in large numbers in intertidal to shallow subtidal habitats. This same species is also found in ancient communities preserved in the richly-fossiliferous Plio-Pleistocene sediments of the Wanganui Basin, North Island, New Zealand, and it is from these sediments that the fossil specimens described in this paper were collected.

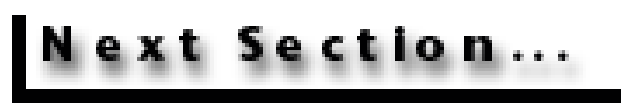




\section{STRATIGRAPHY AND ENVIRONMENT}

The coloured brachiopods were collected from one of the most recent of a remarkable series of marine terraces that provides excellent exposure of the Quaternary sediments in the Wanganui Basin (Figure 1). Running for over $100 \mathrm{~km}$ parallel to the present-day coastline and extending over $20 \mathrm{~km}$ inland at elevations of over $300 \mathrm{~m}$, these terraces are interpreted as the product of Quaternary sea-level fluctuations and tectonic uplift (Fleming 1953; Pillans 1990). In essence, the terraces and their overlying coverbeds are inferred to have been formed during relatively warm interglacial periods when rising sea-levels produced marine transgressions that first cut a terrace in the existing Wanganui sediments and then deposited richly fossiliferous marine sediments. Cold glacial phases would have seen the retreat of the sea and a period of non-deposition. Because of rapid tectonic uplift, these terraces have been protected from subsequent destruction, and a series of 12 terraces has been identified dating back to approximately 700,000 ka (Pillans 1990).

The brachiopods were collected from the basal conglomerate that rests on the Hauriri Terrace (Figure 2). The terraces have been dated using a combination of techniques [fission-track dating, radiocarbon dating, amino acid racemization, and a terrace-deformation model - (Pillans 1990)], and the age of the Hauriri Terrace is interpreted as approximately $80 \mathrm{ka}$. The basal conglomerate would have been deposited pene-contemporaneously with the formation of the terrace which is richly fossiliferous in places. The coloured brachiopods were obtained from a coastal exposure, approximately $250 \mathrm{~m}$ east of the mouth of the

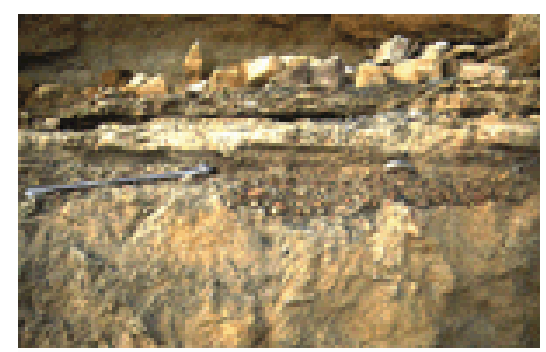

Figure 2. Wairoa Stream, $7 \mathrm{~km}$ from the town of Waverley, South Taranaki (Map Reference N137/170992; Old Series 1inch Map). The fossils are present along a 35-m section of vertical cliff, in a narrow, impersistent, pebbly and conglomeratic bed that has a maximum thickness of approximately $0.2 \mathrm{~m}$ at this locality and is situated about $2 \mathrm{~m}$ above the present beach level.

The locality that yielded coloured brachiopods is close to or at fossil locality G.S. 4174 of Wanganui Memoir of the Geological Survey of New Zealand (Fleming 1953). The coastal section in this area is predominantly composed of unconsolidated sediments that are subject to rapid erosion, and it is possible that the particular exposure yielding coloured fossils was not available to earlier investigators, and the section will shortly be destroyed by erosion. Two species of brachiopod are listed in the Wanganui Memoir as components of an extensive fauna from this and other fossiliferous localities at the base of what was then known as the Rapanui Formation (Fleming 1953). However the Wanganui Memoir makes no mention of the preservation of original colouration at this locality, and the discovery of a single specimen of the 
brachiopod Terebratella sanguinea during the present study is a new addition to the faunal list from the basal conglomerate of the Rapanui Formation. Subsequent work (Pillans 1990) has led to a subdivision of the Rapanui Formation, sensu Fleming 1953.

The fossils were deposited at or below low-tide level off an open eroding coast, and many of the species present are characteristic of present-day eroding coastlines in New Zealand (Fleming 1953). These species, including the brachiopods, are presumed to be indigenous because they are largely intact or cleanly broken and show no signs of abrasions or other damage consistent with significant transportation. A subset of the species recorded are more characteristic of offshore silty and sandy habitats, and these abraded and encrusted shells are thought to have been transported into the area of deposition. A third discrete set of fossils is apparent at this locality--massive oysters and other thick-shelled molluscs that are believed to have been eroded from the gently-dipping fossiliferous Upper Waipipi Shellbed that formed the substrate on which the terrace was formed and the Hauriri sediments were deposited (Fleming 1953). The faunal list compiled by Fleming (1953) includes over 150 different species, the great majority being molluscs, from the several different localities then assigned to the Rapanui Formation.

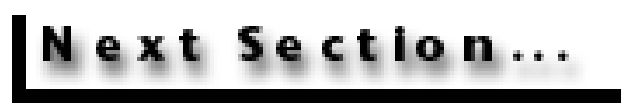




\section{MATERIAL}

The first stage in the collection of brachiopods was to scan the entire exposed section for protruding brachiopods. All brachiopods detected were extracted from these unconsolidated sediments using the blade of a penknife and placed immediately in sample bags wrapped in aluminum foil to exclude light. Reducing the exposure of the coloured fossils to light is likely to be important in preserving original colour because the molecules responsible for shell colouration are known to be sensitive to both light and oxygen (Cheesman et al. 1967). The brachiopods have a patchy distribution along the section, often being clustered around the base of pebbles and boulders, as they would be in life.

Once all surface brachiopods had been collected, the fossil-bearing horizon was excavated using a variety of tools (penknife, trowel, and crowbar), and the majority of brachiopods were collected as they were exposed manually. All sediment debris from the excavations was then sieved using a mesh of $10 \mathrm{~mm}$, and any remaining brachiopods or fragments of brachiopods were collected. All the shells were wet when collected, due to percolation of water through the sequence, but virtually all were in perfect condition. Only two fossils were found in a decayed state--decayed brachiopod shells become soft and very fragile, and terebratulids tend to disintegrate to produce large numbers of microscopic calcite fibres in surrounding sediments (Collins 1986). It is possible that the water-logging noticed in parts of this section is a comparatively recent development caused by the recent damming of the Wairoa Stream. This damming produced a small lake, which is used for industrial purposes.

On the evening of collection all fossils were washed of sediment and then dried between layers of tissue paper. All sample processing was carried out in subdued lighting. During washing it became clear the grey sediment infill often masked the delicate orange-red colour of the fossil terebratulid brachiopods--being very thin shelled, the dominant colouration of brachiopods with a sediment infill was grey. Once dried, the cleaned fossils were placed in sealed black tubes or photographic sample bags that excluded light for transportation back to Glasgow.

In Glasgow, the specimens were stored in plastic containers inside black plastic photographic bags, and exposure to light was minimized. Specimens were photographed uncoated using a Nikon DCS 410 digital camera, and the resulting images processed using Adobe Photoshop software ${ }^{\mathrm{TM}}$. All illustrated specimens have been deposited in the collections of the Hunterian Museum, University of Glasgow, Scotland (GLAHM).

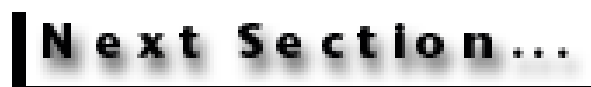




\section{ORIGINAL SHELL COLOURATION}

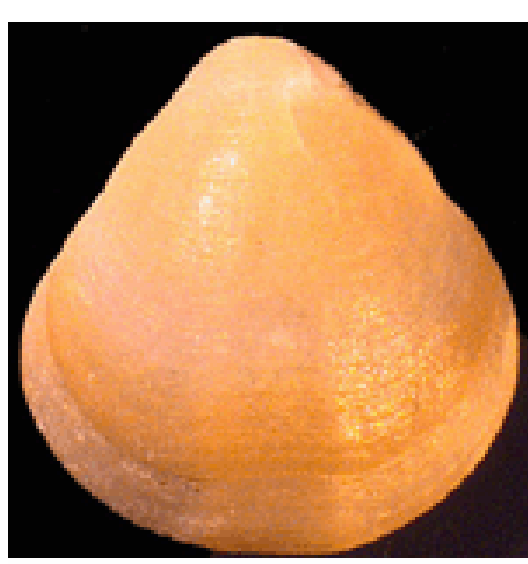

Figure 3.

While collecting the brachiopods it became clear that all of the relatively restricted range of taxa present at this locality displayed undoubted preservation of original colouration. The orange-red colouration of Calloria inconspicua (Figures $3,4,5$ ) and of the single specimen of Terebratella sanguinea discovered (Figure 6) was particularly distinctive, but the other brachiopod present in some abundance, the rhynchonellid Notosaria nigricans, also displayed preservation of its less obvious black to brownish colouration. Other molluscan taxa displayed original shell colouration (Figure 7), indicating that fossilisation and diagenetic conditions have favoured the survival of colour pigments at this locality.

On the first day of collecting, the brachiopods exposed on the surface of the fossiliferous layer were isolated from those collected from within the sediment, and the state of colour preservation was assessed separately. Although the method of assessment is subjective, depending on a visual assessment under subdued lighting, it reinforced the

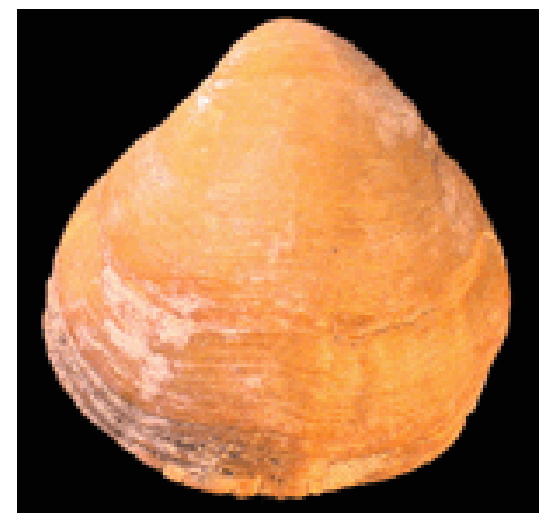

Figure 4. impression that developed during collection that the specimens exposed at the surface displayed poorer colour preservation than those still entombed in sediment. Of the 54 complete or fragmented specimens of Calloria

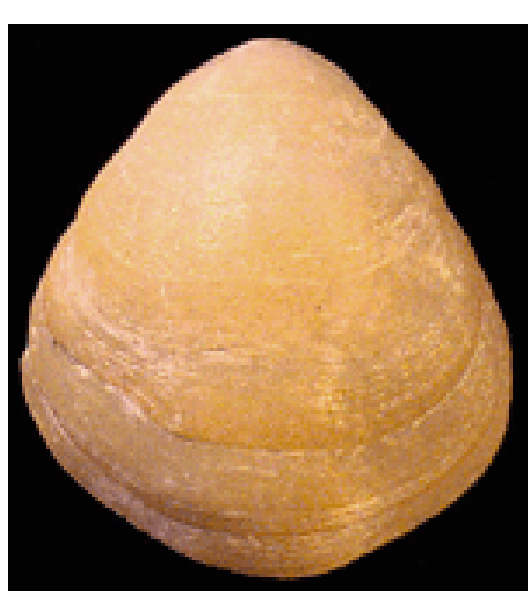

Figure 5. inconspicua that were exposed at the surface of the sediment, a total of $36(67 \%)$ had obvious signs of colour preservation when washed of sediment. It was more difficult to assess the colour survival in specimens of Notosaria nigricans, but a similar exercise was attempted, and the results suggested that only $22 \%$ of specimens exposed at the surface had preserved colouration (5 out of 23 ) as compared with $41 \%$ (17 out of 42 ) from within the sediment.

The subsurface sampling at this locality yielded a total of 323 complete or partial specimens of Calloria inconspicua, and 261 of these had obvious signs of colouration (81\%). The comparable data for Notosaria nigricans were 75 coloured specimens out of a total sample of 179 (42\%). The specimens with the strongest colour preservation were predominantly found underneath or at the side of large pebbles, in crevices between pebbles, or inside large

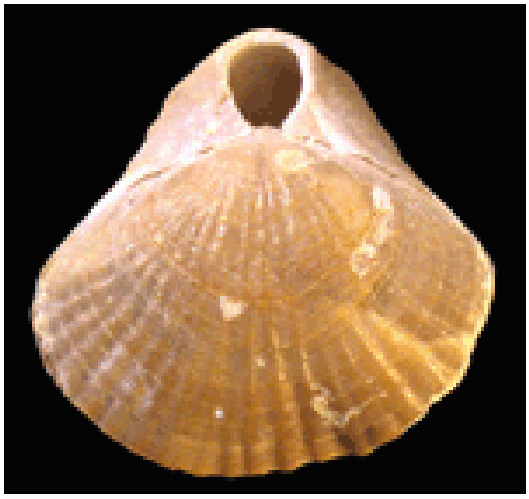

Fiqure 6. 
mollusc shells. The implication is that these individuals were deposited, and fossilized, in cryptic habitats. (Table 1, and Figures $8, \underline{9}$ ).

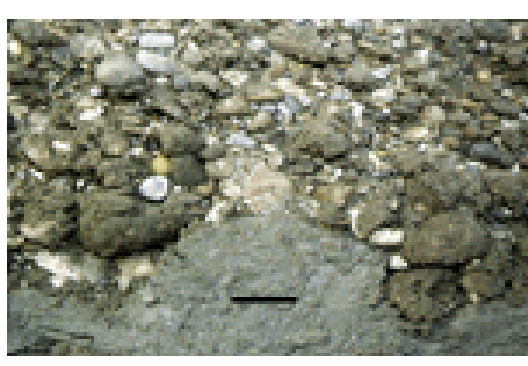

Figure 7.

The indications are that these brachiopods demonstrate the preservation of original shell colouration, rather than post mortem mineralisation or 'contamination' of the sample by Recent specimens. The majority of specimens obtained were collected from within the sediment in positions that rule out any possibility of contamination by Recent specimens. Sessile, pedunculate brachiopods living on this part of the coast since the deposition of the Rapanui sediments would not have been able to penetrate the sediment because they are incapable of burrowing. The presence of coloured brachiopods more than $0.3 \mathrm{~m}$ beneath the sediment surface, leaving clear imprints on the adjacent sediments, and the occurrence of other specimens within the partially open valves of articulated bivalves, guarantees that these are indigenous specimens.

The fossils are much less strongly coloured than living representatives of the species, the shells of which are a bright red colour (Figure 10). The orange-red colour of the

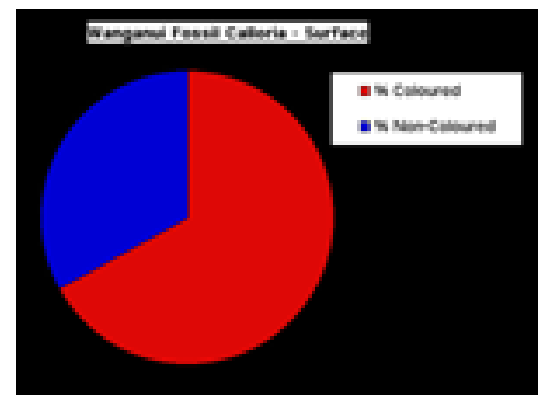

Figure 8.

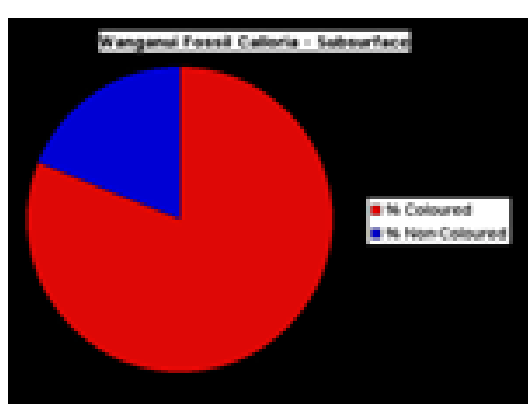

Figure 9. fossils indicates that partial decay

of the molecule responsible for shell colouration has

occurred. In this species the red shell colouration is a result of the presence of a red caroteno-protein that occurs within the crystal of the shell (Curry et al. 1991). As this molecule decays, its colour will change in much the same way that rotten fruit or leaves pass through a variety of colour stages. An amino acid analysis from the fossil shells demonstrated that partial molecular decay had taken place when compared with an equivalent analysis from living representatives of the species (Figure 11, also includes description of the methodology used). The fossil shells are enriched in Glycine $(\mathrm{G})$ and Alanine $(A)$ relative to Recent specimens, and this is expected as fossil shell are characterized by increases in the proportions of these amino acids (because they are formed post-mortem by the decay of less stable amino acids--Curry et al. 1991). The

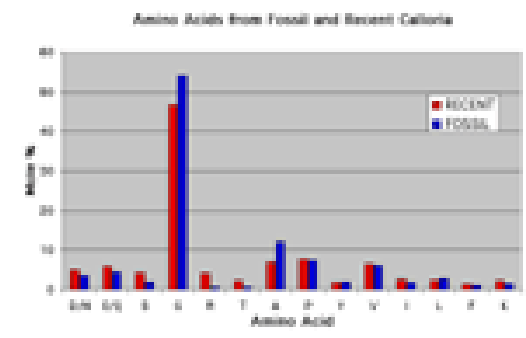

Figure 10. 


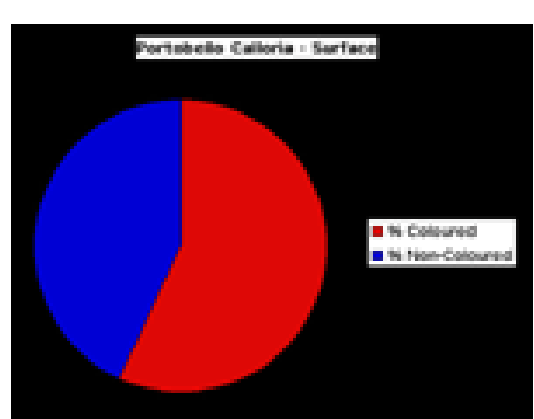

fossils do display a range of colour intensities and hues, suggesting that variable decay of the carotenoid part of the molecule has also taken place. This range of colours present in the fossils is similar to those in living shells, and there is no indication of post-mortem staining by iron-rich solutions that is known to occur in other brachiopods (Zenger 1967).

Figure 11. 


\section{COLOUR SURVIVAL IN A PRESENT-DAY POPULATION}

At the present day brachiopods are not common in inter-tidal habitats, but Calloria inconspicua is found in a few very shallow water localities around New Zealand. The colouration of living and subfossil specimens of one of these intertidal populations has been studied to investigate the pattern of colour decay. Although the Portobello locality differs in some respects from that inferred for the Wanganui Basin fossils, it does provide a rare and invaluable opportunity to investigate brachiopod colour survival in an enclosed shallow water environment.

Large numbers of living Calloria have been recorded from the Otago Peninsula on the South Island of New Zealand. One important locality close to the Portobello Marine Laboratory is in a long, narrow cave excavated in volcanic rocks. This cave has a prominent lip at the seaward entrance, which restricts access to the open sea and indeed isolates the cave at low tides. Calloria inconspicua is abundant in this cave, living at the base of a sloping rock wall and on boulders scattered on the floor of the cave. Significant numbers of these brachiopods are exposed at low tide, although the great majority occurs at and below low tide level. While not directly comparable to the soft-sediment coastline of the Wanganui Basin, the water depths...

In life, most of the cave brachiopods are situated in cryptic habitats out of direct sunlight or are covered by encrusting organisms. However, dead specimens fall onto the cave floor, which is exposed to direct sunlight at the mouth of the cave. The sediment of the cave floor is a very fine-grained greenish silt that is easily disturbed. To investigate the colour survival of dead specimens of Calloria inconspicua, all individuals (either complete specimens or separated dorsal or ventral valves) visible on a $2 \mathrm{~m}^{2}$ section of the cave floor were carefully collected using a snorkel and mask at low tide. This surface collection yielded a total of 281 specimens of which $57 \%$

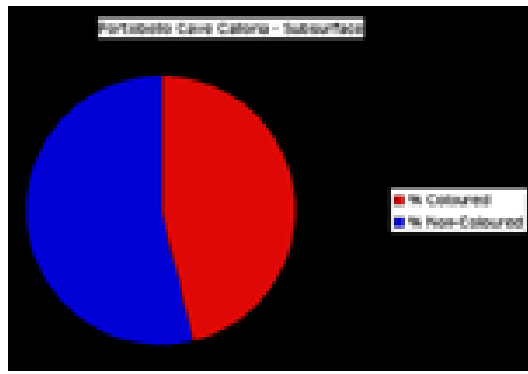

Figure 12. displayed colouration. The upper layers of the sediment were then bulk sampled and sieved to a depth of approximately $50 \mathrm{~mm}$ using a $2-\mathrm{mm}$ sieve, and the resulting sample of an additional 321 Calloria shells contained only $46 \%$ of individuals with discernible colouration (Figures 11 , 12).

In the interest of conservation of

this remarkable locality it was not possible to harvest and sample the living population, but an underwater survey of approximately 100 specimens living attached to the cave wall suggested that at least 95\% had strong colouration (Figure 13). A survey of specimens living in the open sea close to the mouth of the cave indicated that virtually all shells displayed strong red colouration, although assessing colouration in living specimens is problematic because of the prevalence of encrusting

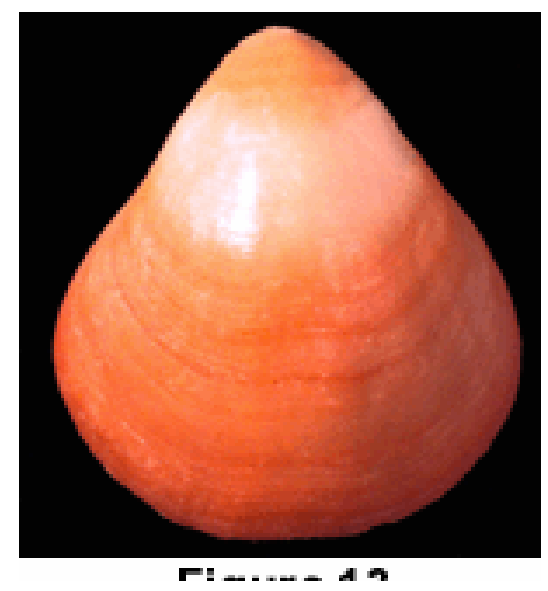


organisms.

rigure I

Sedimentation rates in the cave are likely to be low, and the shells exposed at the surface do become exposed to full sunlight. However these results confirm that brachiopods tend to lose their shell colouration when exposed at sediment surfaces. This decay continues after burial to the extent that more than $50 \%$ of the specimens in the top $50 \mathrm{~mm}$ of sediment lose their colour. The fact that around $80 \%$ of the fossil specimens of Calloria inconspicua displayed some traces of colour after $80 \mathrm{ka}$, as compared with less than $50 \%$ in the top $50 \mathrm{~mm}$ of sediment in the Portobello cave, confirms that the taphonomic conditions at the former locality are unusual.

There is no doubt that the majority of fossil brachiopods lose whatever colour they may have possessed. Virtually nothing is known about the length of time over which brachiopod shell colouration will disappear. Specimens of Calloria inconspicua exposed to daylight for five years show no obvious signs of colour decay. It seems probable that the timing of colour decay will vary depending on taphonomic conditions, and that other factors, such as the nature and effect of percolating groundwater, will also have an effect. Calloria inconspicua itself occurs extensively throughout the Wanganui Basin in 35 horizons ranging in age from approximately 2.98 Ma to $40 \mathrm{ka}$ (see the "Interrograte the Wanganui Database" web site), but this is the first record of any fossil representatives displaying original shell colouration from the Basin. Extensive field investigation of many localities in the Wanganui Basin has failed to reveal any other coloured representatives of Calloria inconspicua, and specimens from the 40 ka locality do not display any colour. It seems likely that rapid burial, presumably associated with the resultant exclusion of light and oxygen, are at least factors in colour survival in the fossil record. Rapid burial is a realistic inference for the fossil Calloria shells in any beach gravel deposited on a marine terrace that is likely to have been formed rapidly in unconsolidated sediments. 


\section{DISCUSSION}

There has been considerable debate about the function of colour molecules in the shells of marine organisms. The red colouration of Calloria specimens comes from a caroteno-protein that occurs within the crystal of the shell. Equivalent pigments from mollusc shells have been considered to be the waste by-product of metabolism (Kelley and Swann 1988), although it has been suggested also that such intra-crystalline biomolecules act as a nucleation site for biomineralisation (Cusack et al. 1992). Carotenoids of the type utilized by brachiopods for colouration are not thought to have been synthethized by the animal, but rather to have been obtained from food, in particular marine algae (Cheesman et al. 1967). Any reduction in the availability of food in the environment inhabited by brachiopods would cause a reduction in the quantity of pigment incorporated within the shell. Such a phenomenon would explain the concentration of colour in growth bands deposited at times when shell-growth was slow (and hence the ratio of ingested pigment to shell growth was relatively high).

Red colouration permeates the body tissues of living brachiopods, as well as the shell (James et al. 1991). Such colouration in other taxa is thought to have an important function in protecting the tissue from potential damage caused by solar radiation (Cheesman et al. 1967). In the case of brachiopods, that would be of greatest significance when planktotrophic larvae of articulated stocks swim to the surface during their free-swimming distribution phase. Among living brachiopods, female gonads are almost always orange or red, or brownish in colour even when the shell itself has no colouration (e.g. Terebratulina retusa - James et al. 1991). In a number of living species it is possible to distinguish the sex of mature individuals without separating the valves as the red colouration of the female gonads is visible through the shell and contrasts with the white or cream-coloured testes (e.g., Rokop 1977).

Red pigmentation of animal shells may have a protective role by warning potential predators that the brachiopod tissues may contain toxins (Fox and Veevers 1960). There have been suggestions that the tissue of articulated brachiopods does contain compounds that are poisonous or unpalatable to potential predators (Thayer and Allmon 1991). Feeding experiments have indicated that marine predators such as snails, crabs, and fish prefer mussels and other bivalves to brachiopods (Thayer 1985). The taxonomic distribution of this trait suggests that unpalatability developed prior to the Ordovician divergence of the rhynchonellid and terebratulid (Thayer and Allmon 1991). Alexander (1986) recorded extensive predation damage in many fossil brachiopods, but only rarely in rhynchonellids and terebratulids. This may, as Thayer (1991) suggested, be a reflection of the unpalatability of these groups. The fact that most records of fossil brachiopods with preserved colour or colour patterns are in rhynchonellid and terebratulid stocks may indicate that this unpalatability was often accompanied by bright warning colouration, as is common in nature (Fox and Veevers 
1960).

On regions of the seabed colonized by coloured encrusting organisms, as happens in the cave investigated on the Otago Peninsula, the shell colouration could also function as camouflage, allowing the organisms to blend in with their environment. If functioning as camouflage, which is again common in nature (Fox and Veevers 1960), the brachiopod colouration is inflexible compared to the ability of some organisms to use different carotenoids for adaptive colour changes in response to different environmental conditions. A new species of Calloria with a striking colouration pattern composed of red straight or cuneiform dashes was recently described from rocky subtidal habitats in Northern New Zealand (Cooper and Doherty 1993). This species,

Calloria variegata, was most abundant in exposed, lower turbidity, clear water environments than the homogeneously coloured Calloria inconspicua (Cooper and Doherty 1993), suggesting that there may well be some adaptive significance for this strikingly different shell colouration pattern.

The fact that it is colouration pattern that is so noticeable, even when pigments have decayed, may mean that important information from the fossil record is being overlooked. Many taxa that do not display colour patterns but are nevertheless strongly but homogeneously coloured will not be so obvious at fossil localities. The fossil shellbeds in the Wanganui Basin are characterized by a wide variety of different hues of greys and browns. These hues may indicate that decayed portions of the original colour molecule survive, even though the great majority of the original shell colouration has disappeared. Studying such degraded colouration is difficult, but some success has been achieved by the use of ultraviolet lighting, because some coloured pigments fluoresce even when partially decayed. In one study, ultraviolet light revealed the presence of radial banding in an Eocene mollusc shell that had revealed no sign of colouration in visible light (Swann and Kelley 1985). The fluorescence of the shells was enhanced by treatment with sodium hypochlorite. Such a technique has not been applied to the specimens in the Wanganui Basin, but may be of use in detecting fossil representatives of Calloria variegata if they are present.

Successful long-term storage of coloured fossils in museums is problematic. Long-term protection of these specimens from the effects of light is relatively straightforward (by storing in light-proof bags and minimising handling), and attempts will be made also to exclude oxygen from a subset of the material stored in the Hunterian Museum by embedding them in a suitable medium such as a resin. Over a period of years it may then be possible to investigate whether other factors apart from the exclusion of oxygen and light are implicated in the survival of colour over geological time spans.

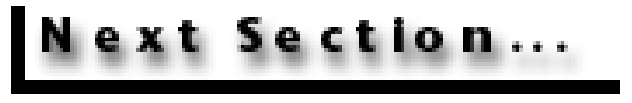




\section{ACKNOWLEDGEMENTS}

I am grateful to many colleagues who helped or participated in New Zealand fieldwork, in particular to John Jellitt and Keith Property of the Portobello Marine Laboratory, University of Otago, Otago, New Zealand.

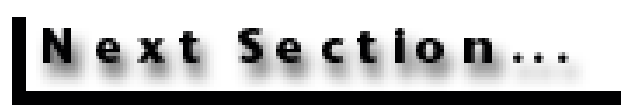




\section{Iose Window}

\section{REFERENCES}

Alexander, R.R. 1986. Frequency of sublethal shell-breakage in articulate brachiopod assemblages through geologic time. In P.R. Racheboeuf and C. Emig, eds, Les Brachiopodes Fossiles et Actuels, Biostratigraphie du Paleozoique, 4, 159-167.

Biernat, G. 1984. Colour pattern in Middle Devonian rhynchonellid brachiopods from the Holy Cross Mountains. Acta Geologica Polonica, 34: 63-72.

Blodgett, R. B., Boucot, A. J., Koch, W. F. 1988. New occurrences of color patterns in Devonian articulate brachiopods. Journal of Paleontology, 62: 46-51.

Blumer, M. 1965. Organic pigments: their long-term fate. Science, 149: 722-726.

Cheesman, D. F., Lee, W. L., and Zagalsky, P. F. 1967. Carotenoproteins in invertebrates.

Biological Reviews, 42: 131-160.

Collins, M.J. 1986. Post-mortality strength loss in brachiopods from the west coast of Scotland. In Racheboeuf, P.R. and Emig, C. (ed), Brachiopods Fossiles et Actuels, Biostratigraphie du

Paeozoique, 4: 209-218.

Cooper, G. A., and Doherty, P. J. 1993. Calloria variegata, a new Recent species of brachiopod (Articulata: Terebratulida) from northern New Zealand. Journal of the Royal Society of New Zealand, 23: 271-281.

Cooper, G. A., and Lee, D. E. 1993. Calloria, a replacement name for the Recent brachiopod genus Waltonia from New Zealand. Journal of the Royal Society of New Zealand, 23: 257-270.

Curry, G. B., Cusack, M., Walton, D., Endo, K., Clegg, H., Abbott, G., and Armstrong, H. 1991. Biogeochemistry of Recent and fossil brachiopod intracrystalline molecules. Philosophical Transactions of the Royal Society of London, B333: 359-366.

Cusack, M., Curry, G. B., Clegg, H., Abbott, G., and Armstrong, H. A. 1992. An intracrystalline chromoprotein from red invertebrate shells; the implications for biomineralization. Comparative Biochemistry Physiology, 102B:93-95.

Fleming, C. A. 1953. The geology of the Wanganui Subdivision. Wellington: Department of Scientific and Industrial Research, Wellington.

Fox, H. M., and Vevers, G. 1960. The Nature of Animal Colours. London: Sidgwick \& Jackson.

Hoare, R. D. 1978. Annotated bibliography on preservation of color patterns on invertebrate fossils. The Compass of Sigma Gamma Epsilon, 55:39-63.

James, M., Ansell, A. D., and Curry, G. B. 1991. Oogenesis in the articulate brachiopod Terebratulina retusa. Marine Biology, 111:411-423.

Kelley, P. H., and Swann, C. T. 1988. Functional Significance of preserved colour patterns of mollusks from the Gosport Sand (Eocene) of Alabama. Journal of Paleontology, 61:83-87.

Pillans, B. 1990. Late Quaternary Marine Terraces. South Taranaki - Wanganui. New Zealand Geological Survey Miscellaneous Map 18, Wellington: Department of Scientific and Industrial Research, Wellington. 
Rokop, F.J. 1977. Seasonal reproduction of the brachiopod Frieleia halli and the scaphopod Cadulus californicus at bathyal depths in the deep ocean. Marine Biology, 43, 237-246

Swann, C. T., and Kelley, P. H. 1985. Residual color patterns in mollusks from the Gosport Sand (Eocene), Alabama. Mississippi Geology, 5:1-8.

Thayer, C.W. 1985. Brachiopods versus mussels: competition, predation and palatability. Science, 228: $1527-1528$.

Thayer, C.W. and Allmon, R.A. 1991. Unpalatable thecideid brachiopods from Palau: Ecological and evolutionary implications. p 253-260. In Mackinnon, D. I., Lee, D. E., and Campbell, J. D. (ed), Brachiopods Through Time. , Balkema, Rotterdam.

Zenger, D. H. 1967. Coloration of the "Pink Chonetes" (Brachiopod) of the Onondaga Limestone, New York. Journal of Paleontology, 41:161-166. 


\section{Close Windo w}

Figure 1. Outline location map of New Zealand showing the fossil brachiopod locality in the Wanganui Basin on the North Island and the Recent brachiopod locality investigated on the Otago Peninsula of the South Island.
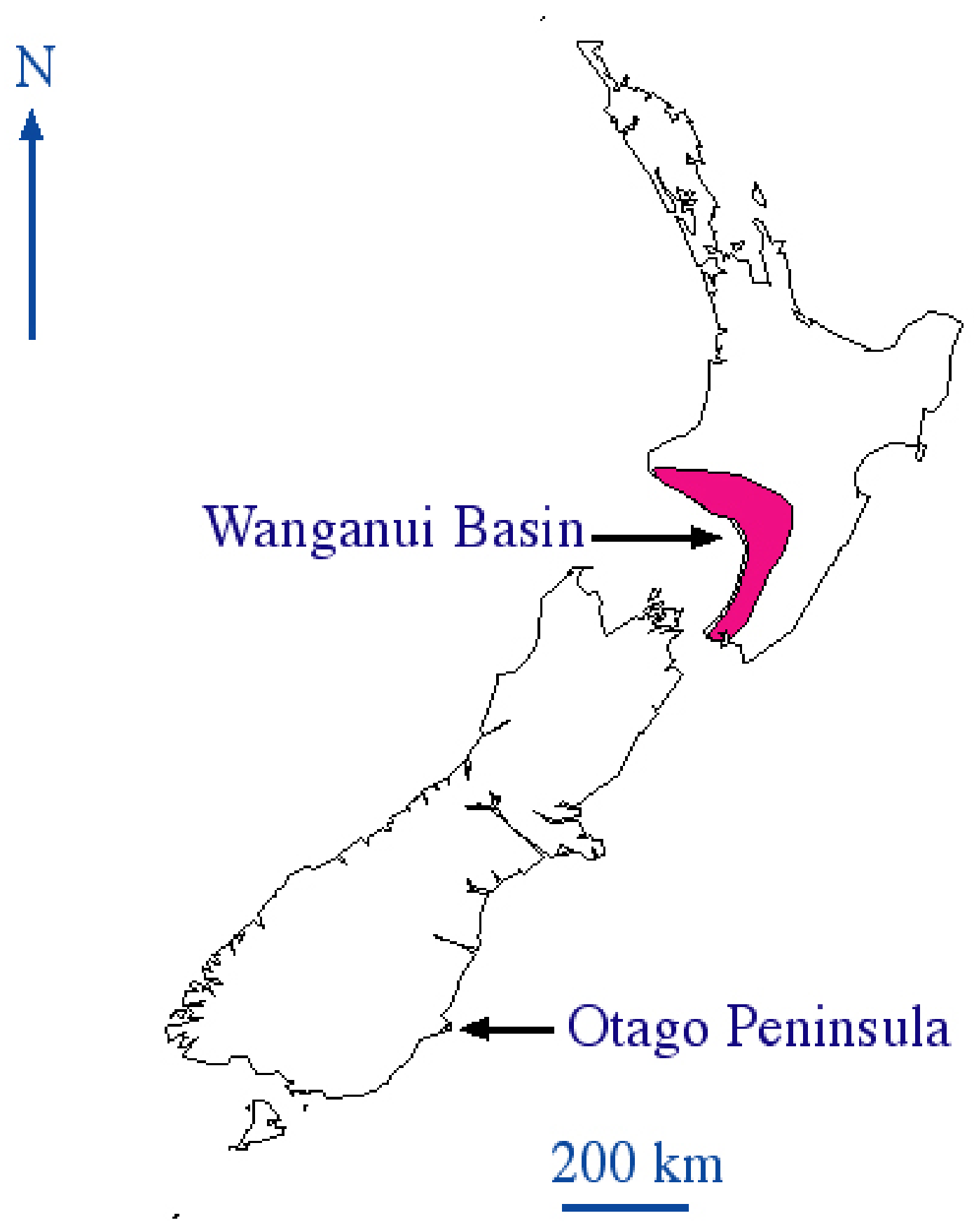


\section{Close Window}

Figure 2. The locality that yielded the coloured fossil brachiopods close to the mouth of the Wairoa River, Wanganui Basin, North Island, New Zealand. The irregular erosional base of the conglomeratic layer containing the fossils is very obvious. The crowbar is $550 \mathrm{~mm}$ in length.

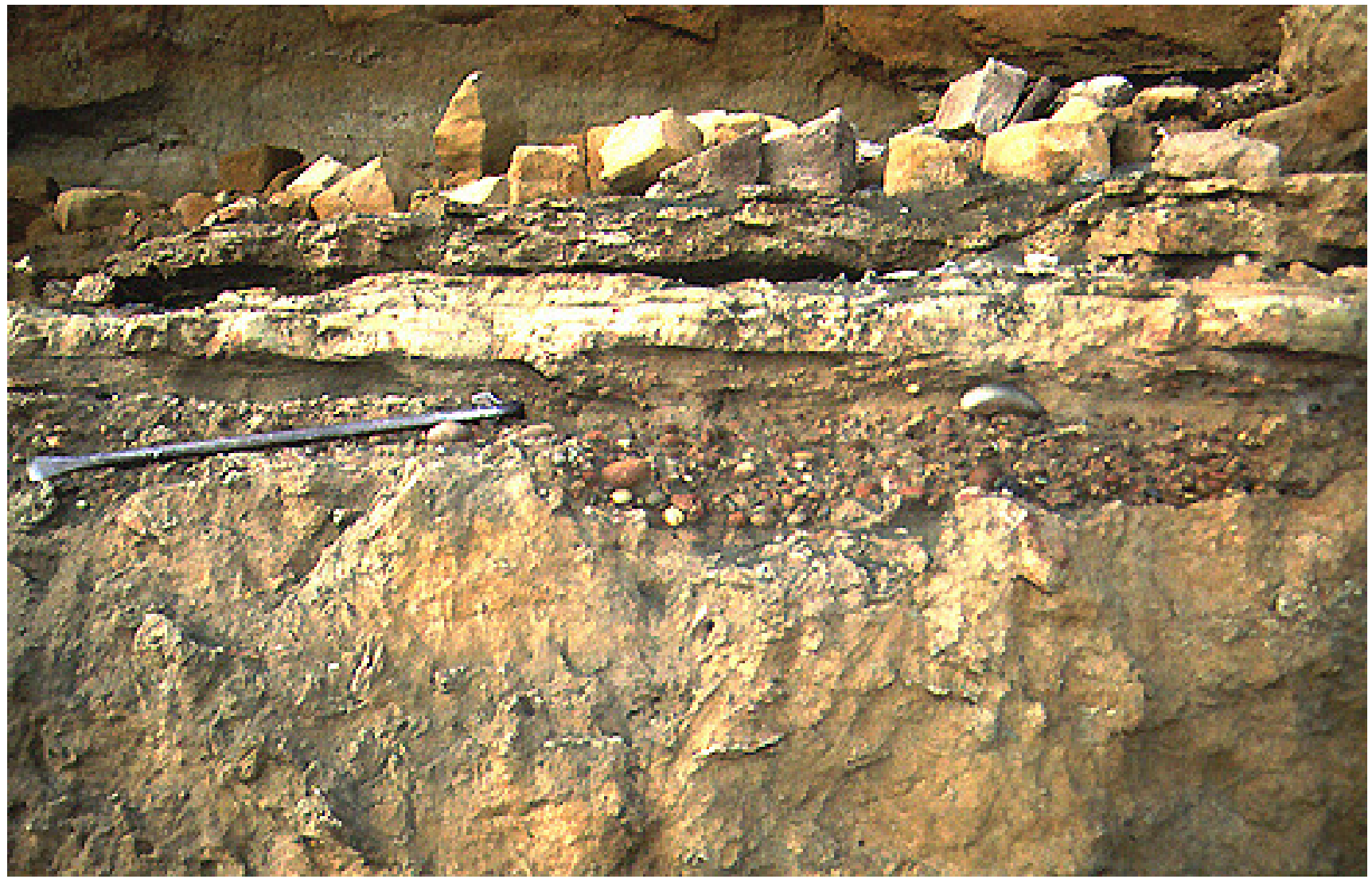




\section{Close W indow}

Figure 3. Ventral valve of fossil Calloria inconspicua showing concentric colouration that becomes most pronounced at growth lines. The specimen (GLAHM 101979) is $16.0 \mathrm{~mm}$ long and $14.5 \mathrm{~mm}$ wide.

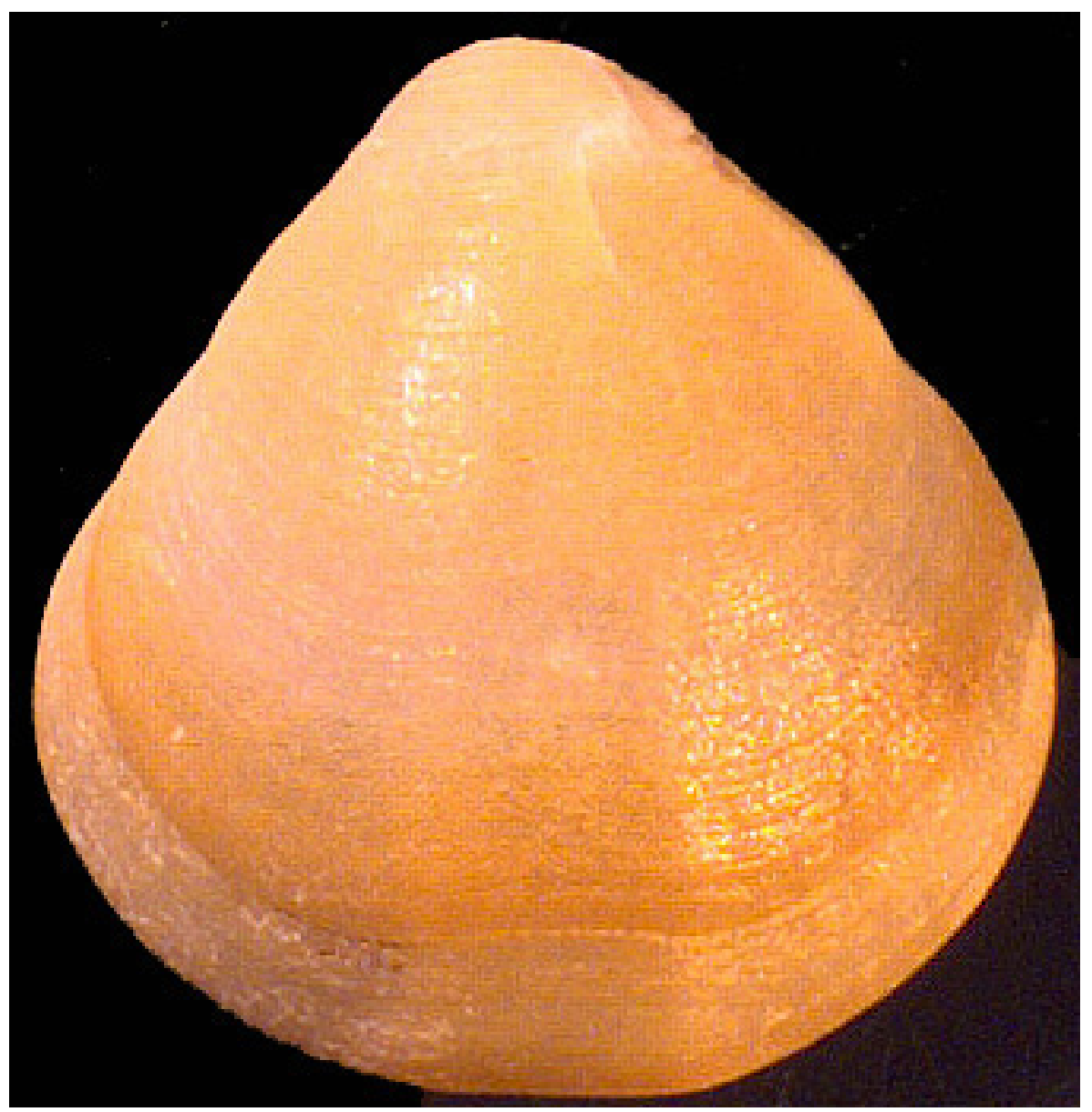




\section{Close Window}

Figure 4. Incomplete ventral valve of Calloria inconspicua showing shell colouration. The specimen (GLAHM 101980) is $17.0 \mathrm{~mm}$ long and $15.1 \mathrm{~mm}$ wide.

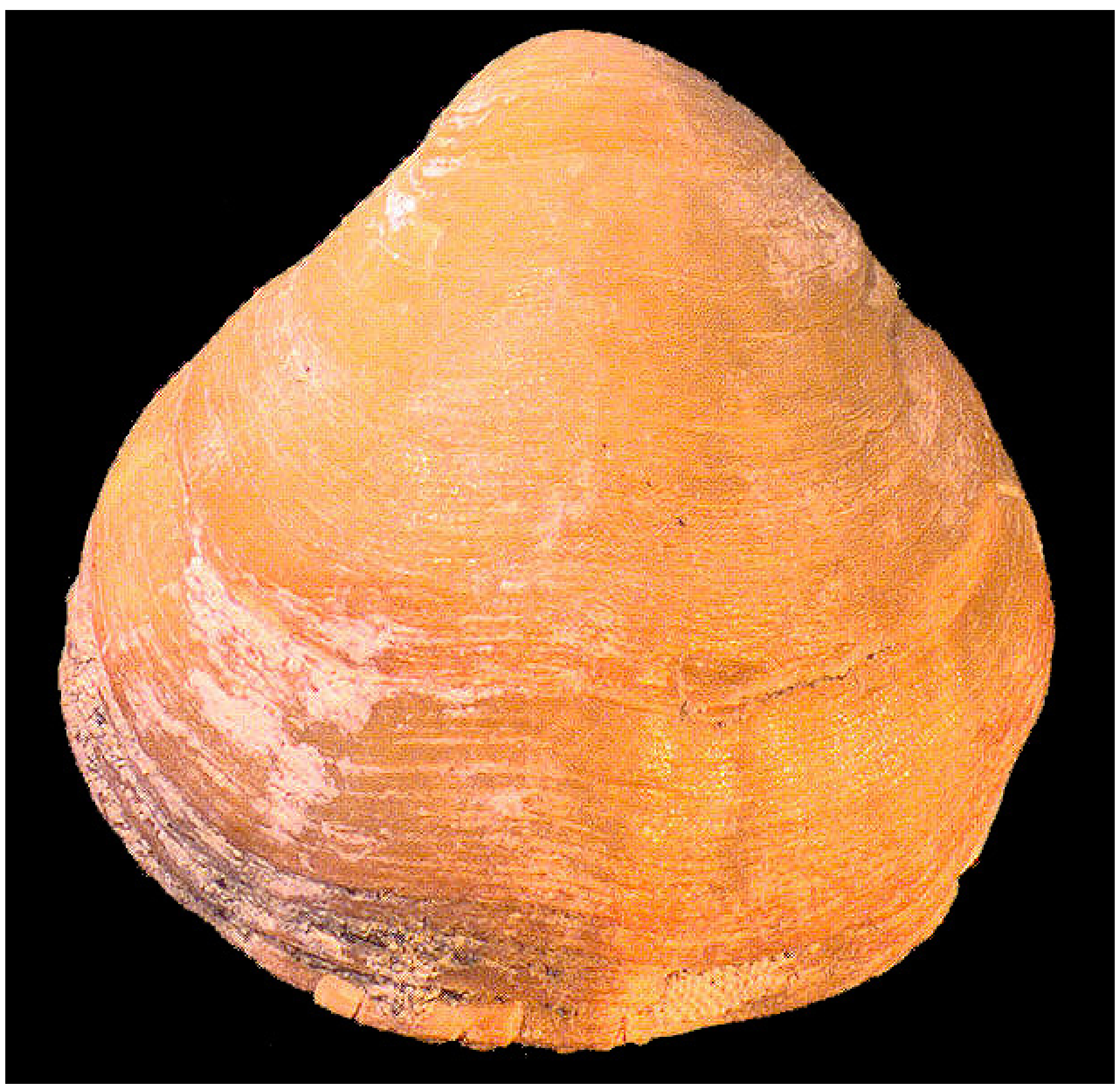




\section{Close Window}

Figure 5. Ventral valve of Calloria inconspicua showing conspicuous concentric colour banding. The specimen (GLAHM 101970) is $13.3 \mathrm{~mm}$ long and $12.1 \mathrm{~mm}$ wide.

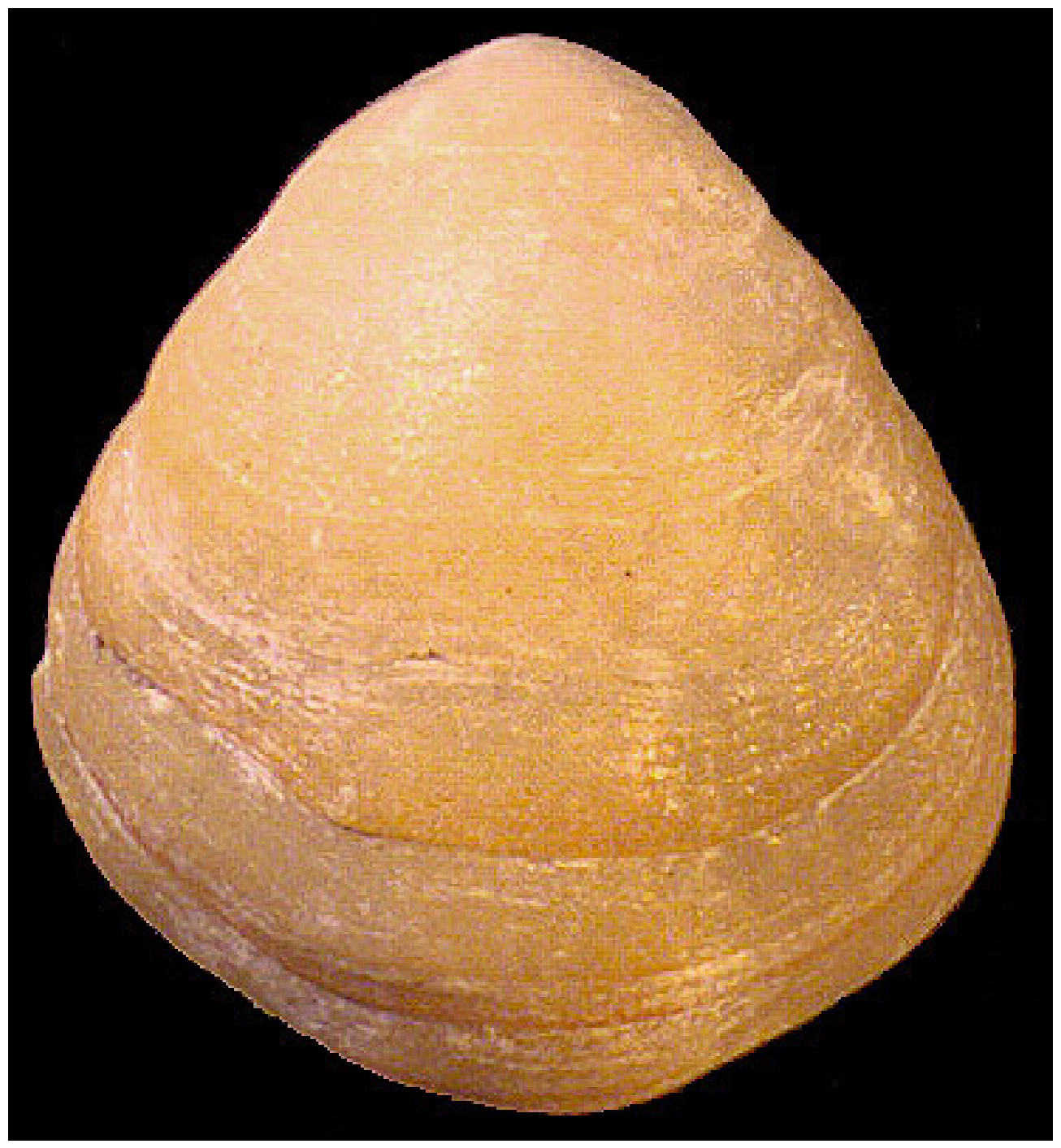




\section{Close Window}

Figure 6. Complete dorsal and ventral valves of Terebratella sanguinea showing shell colouration. The specimen (GLAHM 101978) is $18.0 \mathrm{~mm}$ long and $18.1 \mathrm{~mm}$ wide.

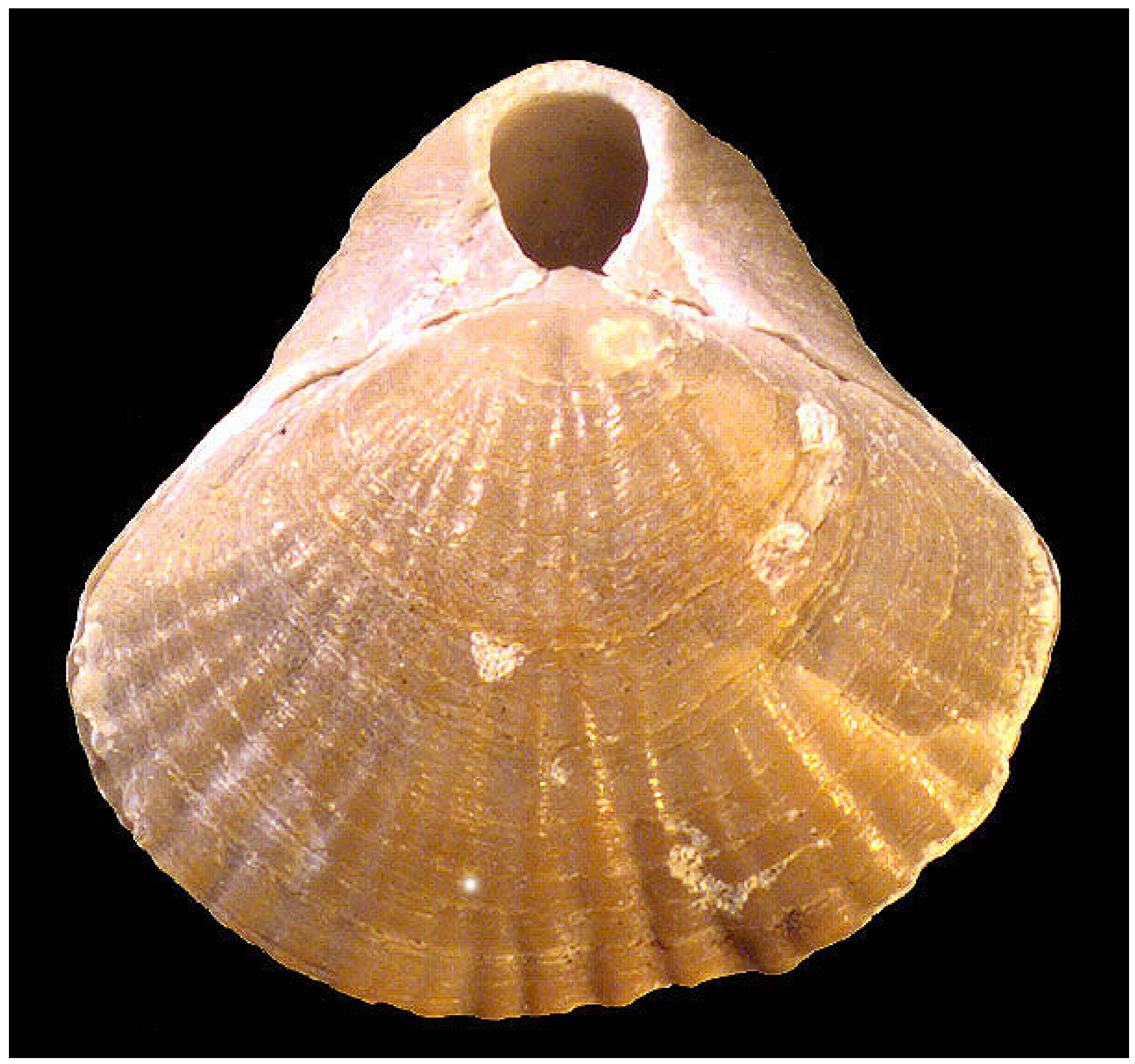




\section{Close Window}

Figure 7. In situ specimen of Chalmys sp, showing preservation of original shell colouration. The scale bar is $50 \mathrm{~mm}$ long.

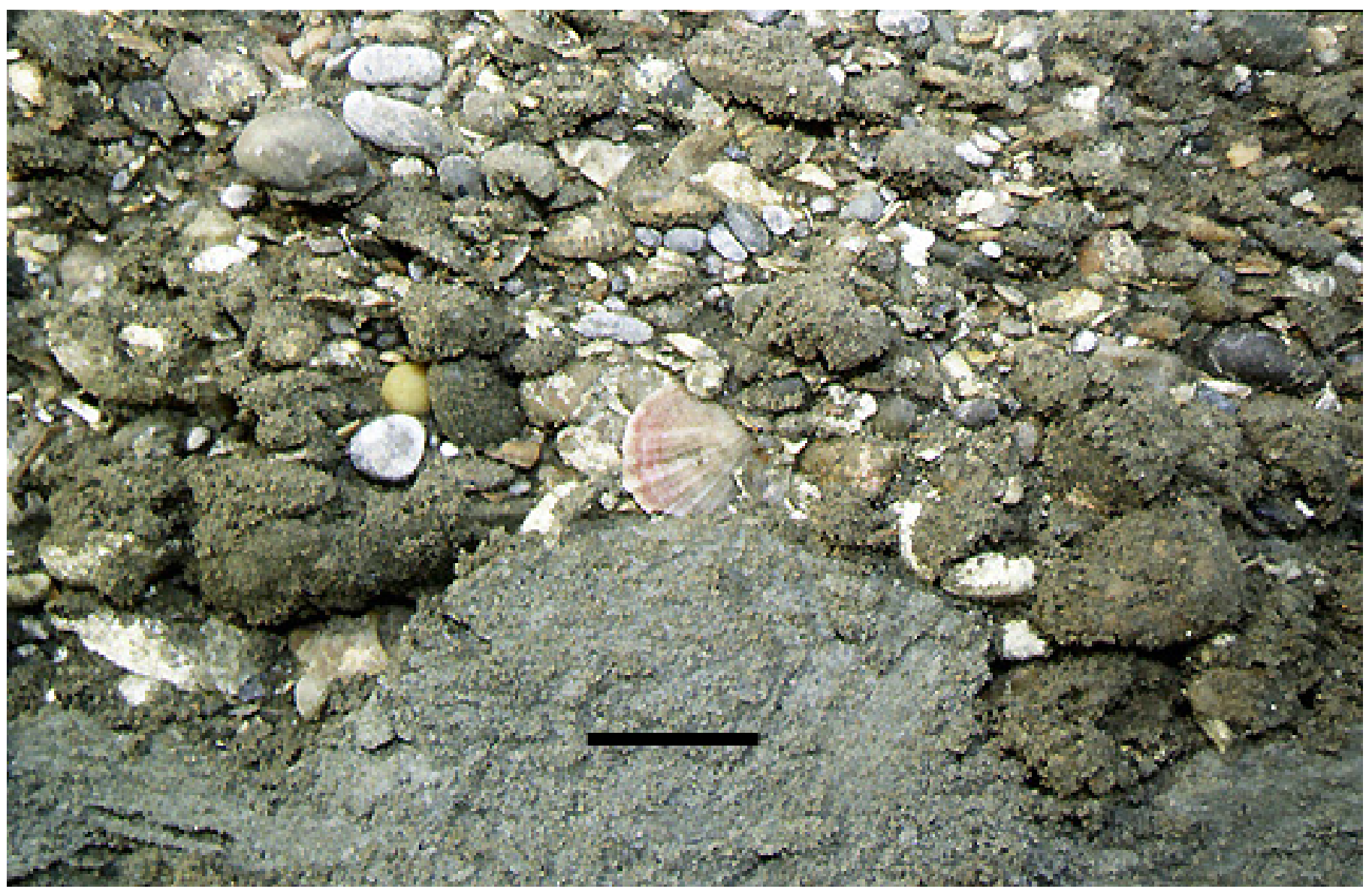




\section{Close Window}

Figure 8. Pie chart showing the percentage of coloured and non-coloured fossil shells of Calloria inconspicua exposed at the sediment surface in the Wanganui Basin.

\section{Wanganui Fossil Calloria - Surface}

$\square \%$ Coloured

— \% Non-Coloured 


\section{Close Window}

Figure 9. Pie chart showing the percentage of coloured and non-coloured fossil shells of Calloria inconspicua exposed by excavations beneath the sediment surface in the Wanganui Basin.

\section{Wanganui Fossil Calloria - Subsurface}

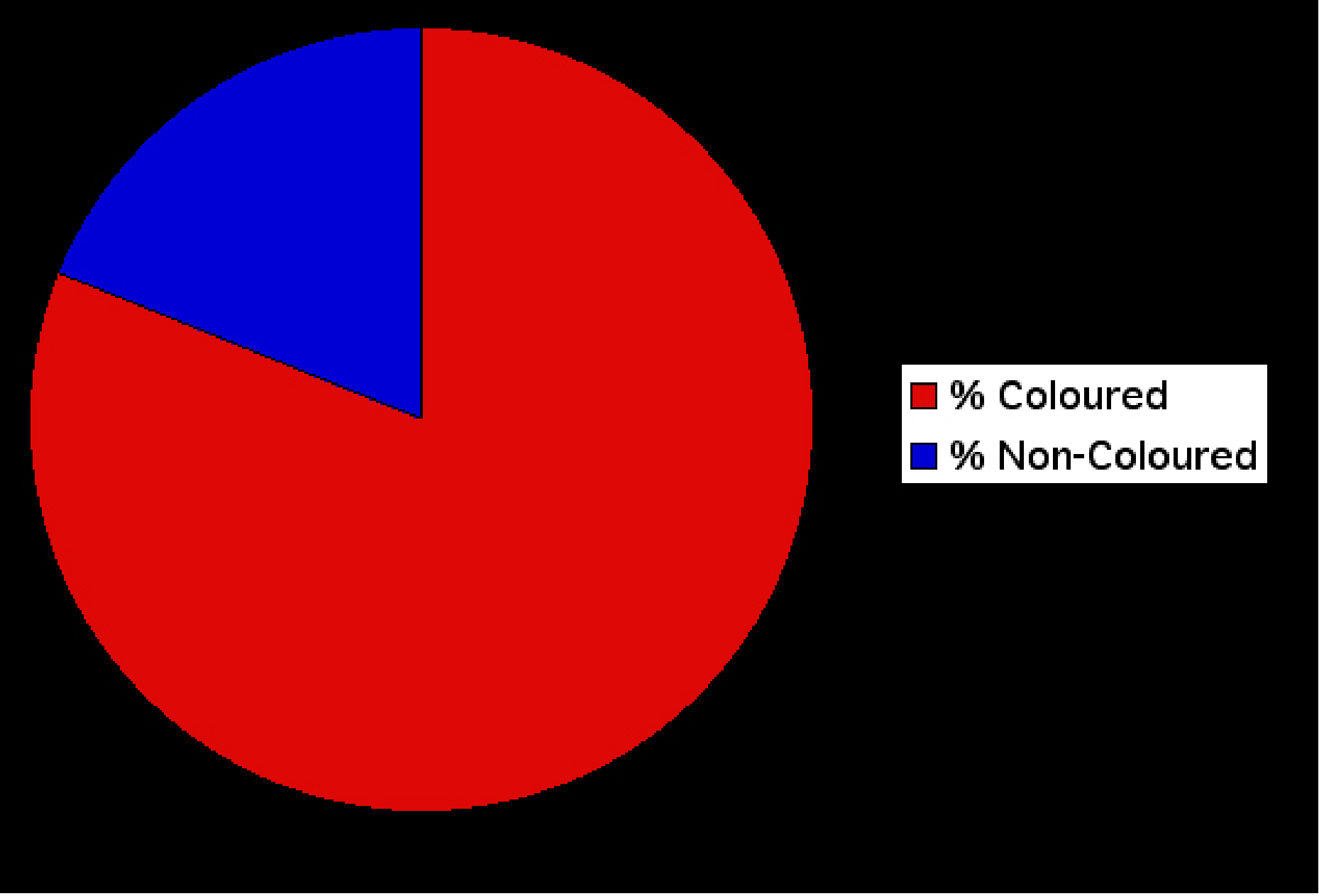




\section{Close W indow}

Figure 10. Comparison of the amino acid composition of the shells Recent and fossil representatives of Calloria inconspicua. The protocol for the extraction and analysis of intracrystalline amino acids from fossils is described in full in Curry et al. 1991. In this case the amino acid data were obtained in replicate following manual hydrolysis using an $\mathrm{ABI} 420 \mathrm{H}$ Amino Acid Analyser. Letters on the horizontal axis refer to the different amino acids (see below for key), and the data are presented in mole percentages. For most amino acids the relative proportions found in fossil shells has declined. The exceptions are Glycine and Alanine, which are more abundant in the fossil; the relative proportion of these small amino acids increases in fossils because they are formed by the breakdown of other less stable amino acids (which is common in fossils - see Curry et al. 1991).

$\mathrm{D} / \mathrm{N}=$ Aspartagine/Aspartic acid, $\mathrm{E} / \mathrm{Q}=$ Glutamine/Glutamic acid, $\mathrm{S}=$ Serine, $\mathrm{G}=$ Glycine, $\mathrm{R}=$ Arginine, $\mathrm{T}=$ Threonine, $\mathrm{A}=$ Alanine, $\mathrm{P}=$ Proline, $\mathrm{Y}=$ Tyrosine, $\mathrm{V}=$ Valine, $\mathrm{I}=$ Isoleucine, $\mathrm{L}=$ Leucine, $\mathrm{F}=$ Phenylalanine, $\mathrm{K}=$ Lysine.

\section{Amino Acids from Fossil and Recent Calloria}

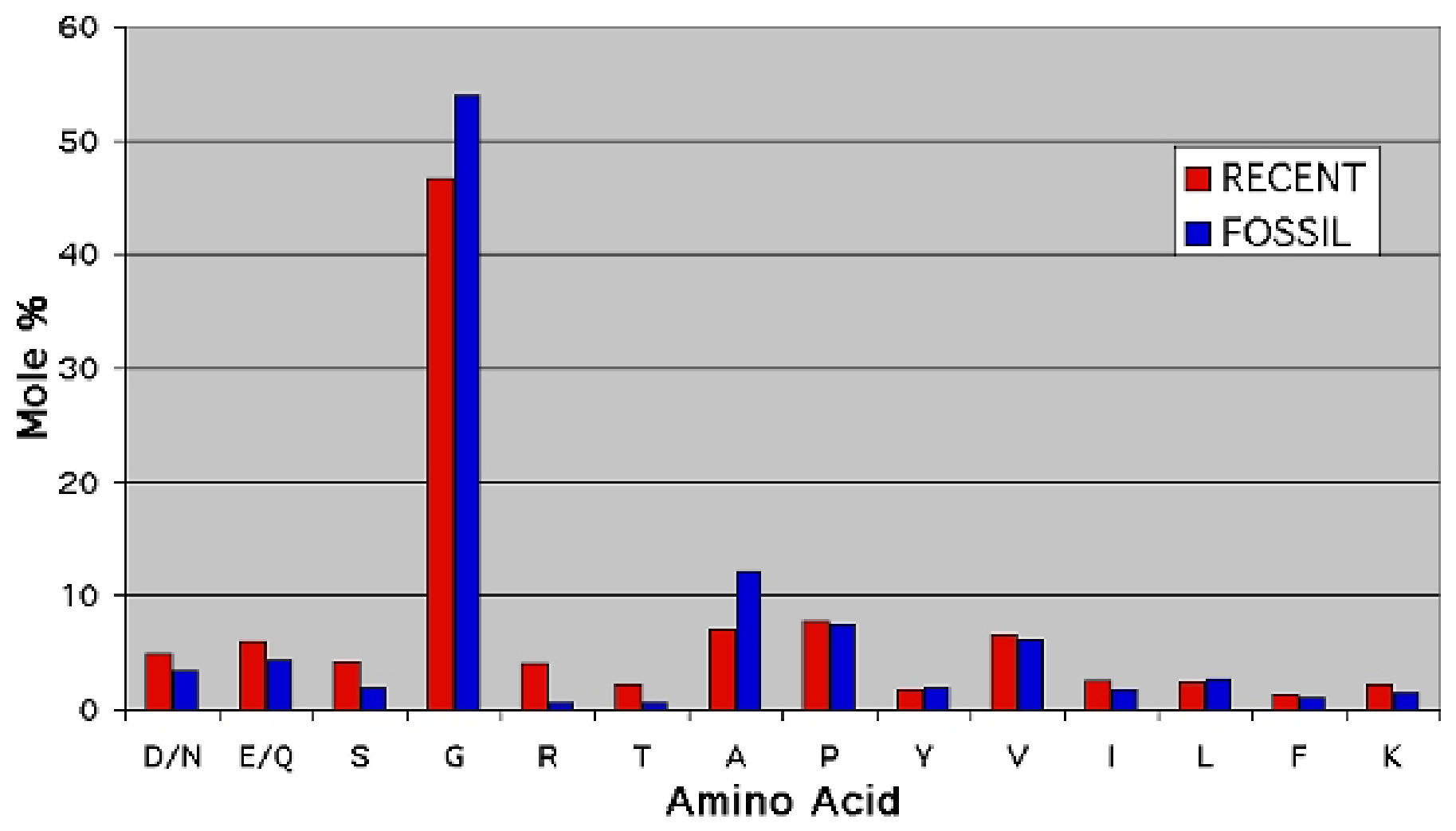




\section{Close Window}

Figure 11. Pie chart showing the percentage of coloured and non-coloured Recent and sub-fossil shells of Calloria inconspicua exposed at the sediment surface in the Portobello Cave.

\section{Portobello Calloria - Surface}

$\%$ Coloured

$\%$ Non-Coloured 


\section{Close Window}

Figure 12. Pie chart showing the percentage of coloured and non-coloured Recent and sub-fossil shells of Calloria inconspicua exposed by excavation of the top $50 \mathrm{~mm}$ of the sediment surface in the Portobello Cave.

\section{Portobello Cave Calloria - Subsurface}




\section{Close Window}

Figure 13. Recent specimen of Calloria inconspicua showing the characteristic strong red colouration. The specimen, which is $16.2 \mathrm{~mm}$ long and $14.1 \mathrm{~mm}$ wide, also shows a pale area of shell posteriorly corresponding to the early stage of growth when rates of shell deposition are greatest. Growth-lines, especially those situated anteriorly, show the strongest colouration, as in the fossil shells.

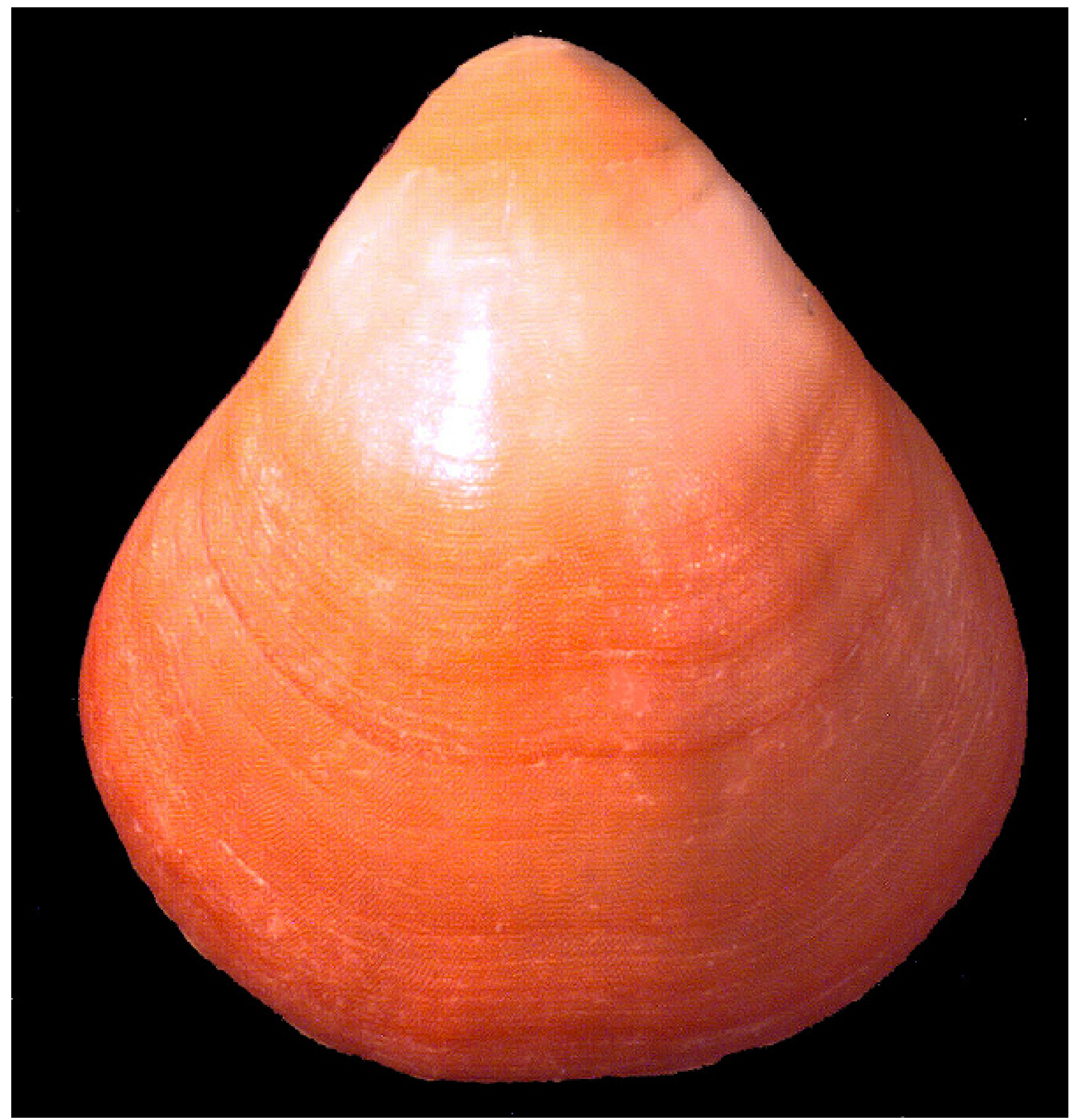




\section{Close Window}

Table 1. Numbers and percentages of Calloria inconspicua and Notosaria nigricans displaying shell colouration in the fossil locality in the Wanganui Basin, New Zealand. Equivalent data for the Recent population of Calloria inconspicua from Portobello Harbour are also presented (Notosaria nigricans is absent from this locality).

\begin{tabular}{|c|c|c|c|c|}
\hline \multicolumn{5}{|c|}{ Calloria inconspicua } \\
\hline & \multicolumn{2}{|c|}{ Wanganui Basin (80 ka) } & \multicolumn{2}{|c|}{ Portobello Harbour (Recent) } \\
\hline & $\begin{array}{l}\text { Total } \\
\text { Number } \\
\text { of shells }\end{array}$ & $\begin{array}{c}\text { Number(\%) } \\
\text { Coloured }\end{array}$ & \begin{tabular}{|c|} 
Total \\
Number of \\
shells
\end{tabular} & Number(\%)Coloured \\
\hline Surface & 54 & $36(67 \%)$ & 281 & $160(57 \%)$ \\
\hline Subsurface & 323 & $261(81 \%)$ & 321 & $148(46 \%)$ \\
\hline \multicolumn{5}{|c|}{ Notosaria nigricans } \\
\hline & \multicolumn{2}{|c|}{ Wanganui Basin (80 ka) } & & \\
\hline & $\begin{array}{l}\text { Total } \\
\text { Number } \\
\text { of shells }\end{array}$ & $\begin{array}{l}\text { Number(\%) } \\
\text { Coloured }\end{array}$ & & \\
\hline Surface & 23 & $5(22 \%)$ & - & - \\
\hline Subsurface & 179 & $75(42 \%)$ & - & \\
\hline
\end{tabular}

